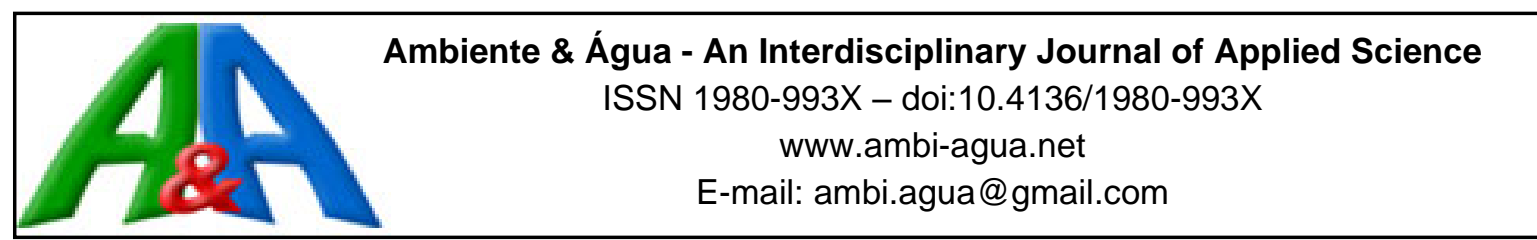

\title{
The role of food/microorganism ratio in denitrification reactors: how it affects the sizing and operation of the denitrification process
}

\author{
ARTICLES doi:10.4136/ambi-agua.2656 \\ Received: 05 Oct. 2020; Accepted: 17 Nov. 2020

\begin{abstract}
Renato Gavasci $^{1(\mathbb{D})}$; Francesco Lombardi ${ }^{1 *}$; Massimo Raboni ${ }^{2}$ (I)
${ }^{1}$ Department of Civil Engineering and Computer Science Engineering. Università degli Studi di Roma Tor Vergata, Via Politecnico 1, 00133, Rome, Italy. E-mail: gavasci@ing.uniroma2.it

${ }^{2}$ Department Hydraulics and Environmental Engineering. University of Pavia, Corso Str. Nuova, n 65, 27100, Pavia, Italy. E-mail: massimo.raboni@gmail.com

*Corresponding author. E-mail: lombardi@ing.uniroma2.it
\end{abstract}

\begin{abstract}
Two calculation models of the Specific Denitrification Rate (SDNR) are analyzed to highlight the sensitivity of this parameter to the Food:Microorganisms ratio in the denitrification reactor $\left(\mathrm{F}: \mathrm{M}_{\mathrm{DEN}}\right)$. One of these models is empirical while the second was

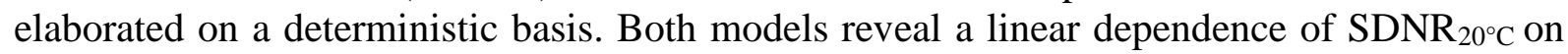
F:M DEN and in a first approximation they are comparable only in a narrow range of concentration of dissolved oxygen (DO) in denitrification, specifically $\mathrm{DO}=0.25-0.35 \mathrm{mg} \mathrm{L}^{-1}$. These values frequently occur in well designed and well operated sewage treatment plants. Outside this range, the role of F:M $\mathrm{M}_{\mathrm{DEN}}$ must necessarily be examined in combination with DO because of the relevant influence of the latter on the efficiency of the denitrification process.
\end{abstract}

Keywords: activated sludge, biological process, denitrification, nitrogen removal, sewage treatment.

\section{O papel da fração alimento/microrganismos nos reatores de desnitrificação: como afeta o dimensionamento e a operação do processo de desnitrificação}

\section{RESUMO}

Dois modelos de cálculo do SDNR-Specific Denitrification Rate são analisados para destacar a sensibilidade deste parâmetro em relação à fração Alimento/Microrganismos no reator de desnitrificação (A: $\left.M_{\mathrm{DEN}}\right)$. Um desses modelos é empírico, enquanto o segundo foi elaborado em uma base determinística. Ambos os modelos revelam uma dependência linear de $\mathrm{SDNR}_{20^{\circ} \mathrm{C}} \mathrm{em} \mathrm{A}: \mathrm{M}_{\mathrm{DEN}} \mathrm{e}$, em primeira aproximação, eles são comparáveis apenas dentro de uma faixa estreita de concentração de oxigênio dissolvido (OD) na desnitrificação, especificamente $\mathrm{OD}=0,25-0,35 \mathrm{mg} \mathrm{L}^{-1}$. Esses valores ocorrem frequentemente em estações de tratamento de esgoto bem projetadas e operadas. Fora dessa faixa, o papel do A:M em combinação com o OD devido à influência relevante deste último na eficiência do processo de desnitrificação.

Palavras-chave: desnitrificação, lodo ativado, processo biológico, remoção de nitrogênio, tratamento de esgoto.

This is an Open Access article distributed under the terms of the Creative Commons Attribution License, which permits unrestricted use, distribution, and reproduction in any medium, provided the original work is properly cited. 


\section{INTRODUCTION}

Physico-Chemical and biological processes are used for the removal of nitrogen from wastewater. The former mainly consists of chlorination or stripping processes and is widely used for the treatment of industrial wastewaters with high concentrations of ammonia (Capodaglio et al., 2015; Raboni et al., 2013a; Raboni and Viotti, 2017). Alternatively, the biological processes are essentially used in the treatment of sewage, as they are significantly cheaper than physico-chemical processes (Copelli et al., 2015; Subtil et al., 2013; Torretta et al., 2014; Collivignarelli et al. 2019, Butzen et al. 2020). At present, the most widely used biological denitrification technology is biological pre-denitrification in activated sludge treatment processes. Figure 1 shows a typical scheme consisting of an anoxic denitrification reactor (DEN) placed upstream of the oxidizing-nitrifying aerobic reactor (OX-NIT), which provides for the removal of $\mathrm{BOD}_{5}$ and the nitrification of total Kjeldhal nitrogen (TKN ) (Ekama et al., 1999; Gerardi, 2002; Ucker et al., 2012; Major Barbosa et al., 2016; Capodaglio et al., 2016; Wuhrmann, 2017; Pereira Ribeiro et al., 2018; Abeysiriwardana-Arachchige et al., 2020; Pires da Silva et al., 2020).

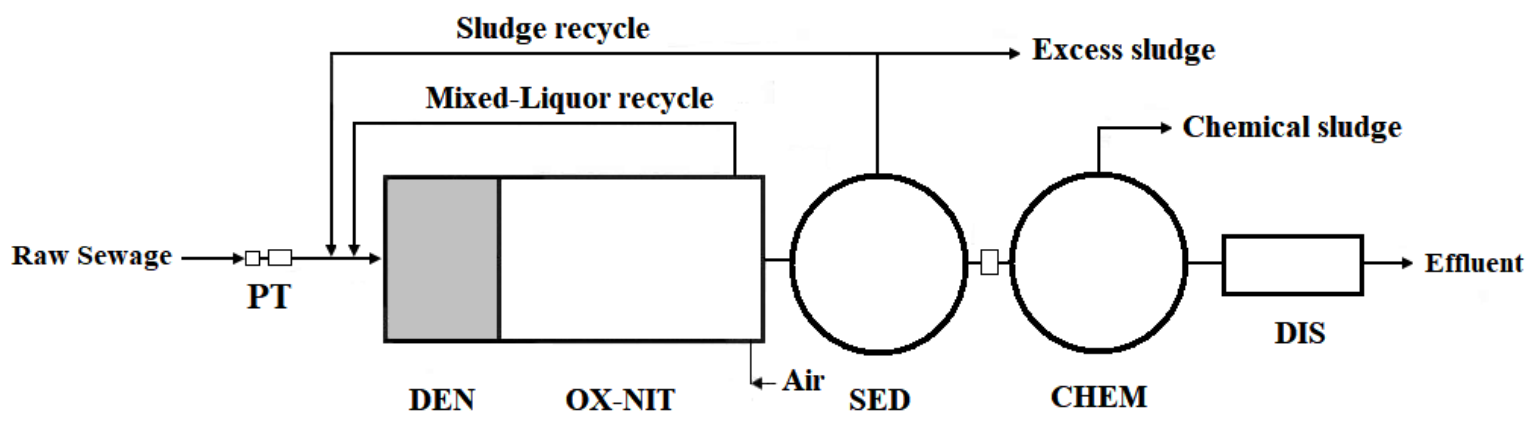

LEGEND:

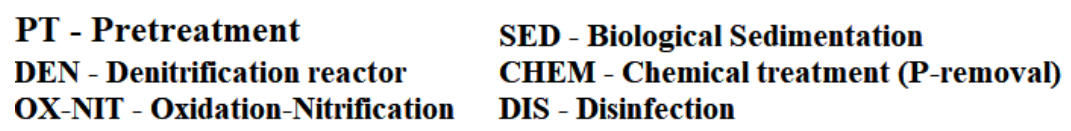

Figure 1. Schematic lay-out of a typical sewage treatment plant with pre-denitrification.

The removal of nitrogen in the pre-denitrification stage is carried out by denitrifying heterotrophic bacteria capable of reducing nitrates to nitrogen gas through a biochemical reaction that uses the $\mathrm{BOD}_{5}$ of the raw sewage as an electron donor. The process has been widely used in full-scale plants for many years. Nevertheless, the scientific research is very active in this field, above all to gain a better understanding of the influence exerted by various parameters on the efficiency of the process, among which is sludge loading in denitrification ( $\left.F: M_{D E N}\right)$. This parameter proved to be important in the sizing of the pre-denitrification reactor.

Currently, the sizing of the denitrification reactor is based on the parameter Specific Denitrification Rate (SDNR) defined as follows (Equation 1):

$S D N R_{T}=\frac{Q N}{V M L V S S}$

The value at the real temperature $T$ of the mixed-liquor can be calculated by the modified Arrhenius Equation 2 (Ekama et al., 2011):

$S D N R_{T}=S D N R_{20}{ }^{\circ} \mathrm{C} \theta^{(T-20)}$

Where: 
$\mathrm{SDNR}_{\mathrm{T}}$ Specific Denitrification Rate at the temperature $\mathrm{T}\left(\mathrm{kgNO}_{3}-\mathrm{N} \mathrm{kgMLVSS}^{-1} \mathrm{~d}^{-1}\right)$

$\mathrm{SDNR}_{20^{\circ} \mathrm{C}}$ Specific Denitrification Rate at the temperature of $20^{\circ} \mathrm{C}\left(\mathrm{kgNO}_{3}-\mathrm{N} \mathrm{kgMLVSS}^{-1} \mathrm{~d}^{-1}\right)$

$\mathrm{Q} \Delta \mathrm{N}$ Load of nitrogen removed in denitrification $\left(\mathrm{kg} \mathrm{d}^{-1}\right)$

MLVSS Mixed-Liquor Volatile Suspended Solids in denitrification ( $\mathrm{kg} \mathrm{VSS} \mathrm{m}^{-3}$ )

$\mathrm{V}$ Volume of the denitrification reactor $\left(\mathrm{m}^{3}\right)$

T temperature $\left({ }^{\circ} \mathrm{C}\right)$

( temperature coefficient: $\theta=1.026$ (USEPA, 2009); $\theta=1.07$ (Tchobanoglous et al., 2003).

As defined, the $\mathrm{SDNR}_{\mathrm{T}}$ is given by two contributions: the biochemical reduction of $\mathrm{NO}_{3}{ }^{-}$ to $\mathrm{N}_{2}$ and the synthesis of new cells.

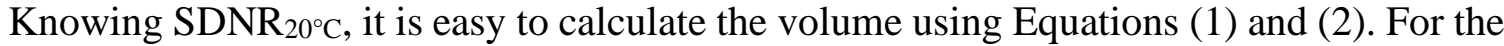
calculation of $\mathrm{SDNR}_{20^{\circ} \mathrm{C}}$ different models are proposed, which take into account the main variables capable of influencing the denitrification kinetics, which specifically are F:M residual oxygen concentration DO.

The present research aims to highlight the influence of $F: M_{D E N}$ in the calculation of

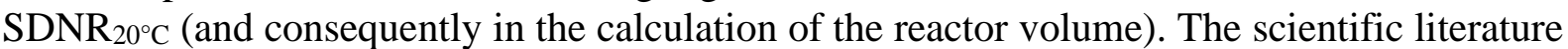
reports various data on this influence (Raboni et al., 2013b; 2014a; 2015)

In full scale plants F:MDEN is often found in the range 0.15-0.40 kg BOD $\mathrm{d}^{-1} \mathrm{kgMLVSS}^{-1}$ (Raboni et al., 2017).

\section{MATERIALS AND METHODS}

The influence of $F: M_{D E N}$ on the sizing of the denitrification reactor can be evaluated

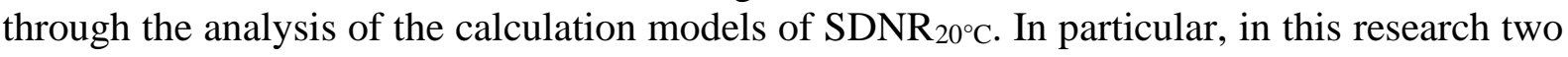
models are considered. The first model (Model I) is very empirical and it correlates $\mathrm{SDNR}_{20}{ }^{\circ} \mathrm{C}$ with only the variable $F: M_{D E N}$. This model was first described by Tchobanoglous et al. (2003). It was later implemented (USEPA, 2010) by introducing a correction factor $F_{b}$ to the $F: M_{D E N}$ (Equation 3).

$S D N R_{20^{\circ} \mathrm{C}}=0.029+0.03 \cdot\left(F_{b} / 0.30\right)\left(F: M_{D E N}\right)$

$F_{b}$ takes into account the greater or lesser concentration of active biomass in the mixedliquor, which in turn depends on the SRT-Sludge Retention Time. For more details on Fb see USEPA (2010). In biological plants with high efficiency for both oxidation-nitrification and denitrification the SRT is normally found in the range 18-20 d. With SRT=20 the factor results $F_{b}=0.35$.

The second model (Model II) is more advanced than the first, as it expresses the dependence of $\mathrm{SDNR}_{20}{ }^{\circ} \mathrm{C}$ not only on $\mathrm{F}: \mathrm{M}_{\mathrm{DEN}}$ but also on DO another variable capable of significantly influencing the efficiency of the denitrification process (Oh and Silverstein, 1999; Plosz et al., 2003; Torti et al., 2013; Urbini et al., 2015; Viotti et al., 2016). This model was elaborated through a deterministic calculation (Raboni et al., 2014b) and then it was validated by a pilot plant study (Raboni et al., 2014a) and by checking many real-scale plants (Raboni and Torretta, 2017) (Equation 4).

$$
S D N R_{20^{\circ} C}=0.0864\left(\frac{K_{O}^{\prime}}{K_{O}^{\prime}+D O}\right)+0.05 F: M_{D E N} \cdot \eta_{B O D} \cdot\left(\frac{D O}{0.2+D O}\right)
$$

Where:

$$
K^{\prime}=0.18 \mathrm{mgO}_{2} \mathrm{~L}^{-1}
$$


$\eta_{B O D}$ : removal efficiency of $\mathrm{BOD}_{5}\left(\eta_{B O D}=0.85-0.95\right.$ depending on the value assumed by $\mathrm{F}: \mathrm{M}_{\mathrm{DEN})}$

\section{RESULTS AND DISCUSSION}

Figure 2 shows the trend of $\mathrm{SDNR}_{20^{\circ} \mathrm{C}}$ as a function of the $\mathrm{F}: \mathrm{M}_{\mathrm{DEN}}$, according to the two models under study. Model II is represented at 5 different DO values. Due to the mathematical structure of the equations, all curves represented are straight lines.

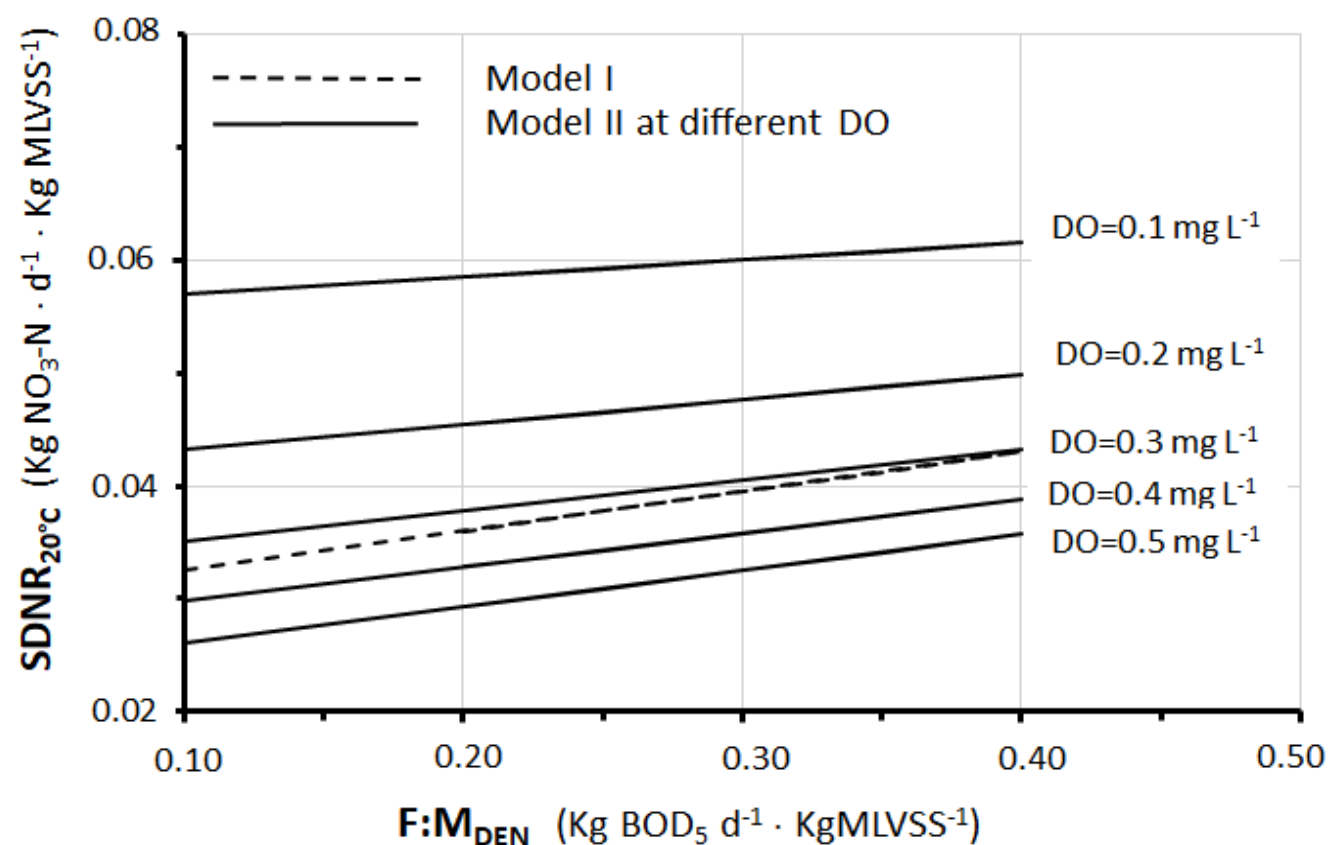

Figure 2. $\mathrm{SDNR}_{20^{\circ} \mathrm{C}}$ as a function of $\mathrm{F}: \mathrm{M}_{\mathrm{DEN}}$, according to the two calculation models (Model II is represented at different DO).

The observation of the Figure leads to three important considerations:

a) the variable $\mathrm{F}: \mathrm{M}_{\mathrm{DEN}}$ affects the $\mathrm{SDNR}_{20^{\circ} \mathrm{C}}$ in a directly proportional way, i.e., each

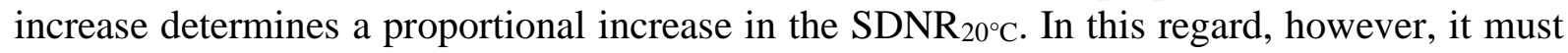
be considered that there is a limit to this progressive growth beyond which a strong wash-out of the denitrifying bacteria can occur. As the denitrifying bacteria are heterotrophic in nature (like BOD oxidizing bacteria), the typical limit not to be exceeded is close to F:M $M_{D E N}=0.40 \mathrm{~kg}$ $\mathrm{BOD}_{5} \mathrm{~d}^{-1} \mathrm{kgMLVSS}^{-1}$ (in plant design a slightly lower values is suggested, close to $0.3 \mathrm{~kg}$ $\left.\mathrm{BOD}_{5} \mathrm{~d}^{-1} \mathrm{kgMLVSS}^{-1}\right)$.

b) DO proves to be a variable of considerable importance, especially if the sizing and operation of the plant are such as to maintain dissolved oxygen concentrations appreciably lower than $\mathrm{DO}=0.3-0.4 \mathrm{mg} \mathrm{L}^{-1}$. For DO below this range, there is a progressive and more than

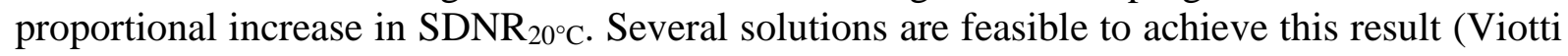
et al., 2016; Urbini et al., 2015)

c) the line of Model I as a first approximation is comparable only with two lines of Model II, those characterized by $\mathrm{DO}=0.3 \mathrm{mg} \mathrm{L}^{-1}$ and $\mathrm{DO}=0.4 \mathrm{mg} \mathrm{L}^{-1}$. In fact, the range $\mathrm{DO}=0.3-0.4$ $\mathrm{mg} \mathrm{L}^{-1}$ is frequently found on full scale plants (Raboni and Torretta, 2017).

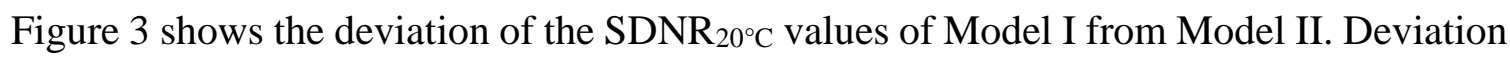
is defined as the \% difference between the $\mathrm{SDNR}_{20}{ }^{\circ} \mathrm{C}$ of the models at the same value of

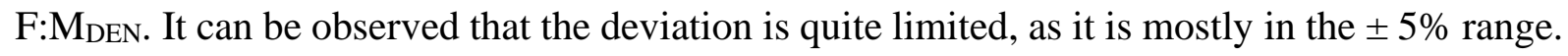


Instead, in Figure 3, which shows the deviation of Model I from Model II (the latter at various DO values), the deviation falls within the range of $5 \%$ only in a very narrow range of DO (approximately DO=0.30-0.35 $\mathrm{mg} \mathrm{L}^{-1}$ ). These findings are a further confirmation of the limited field of validity of the empirical model and also how important is the influence of DO in the denitrification process, especially when the same DO values are outside the above-mentioned range.

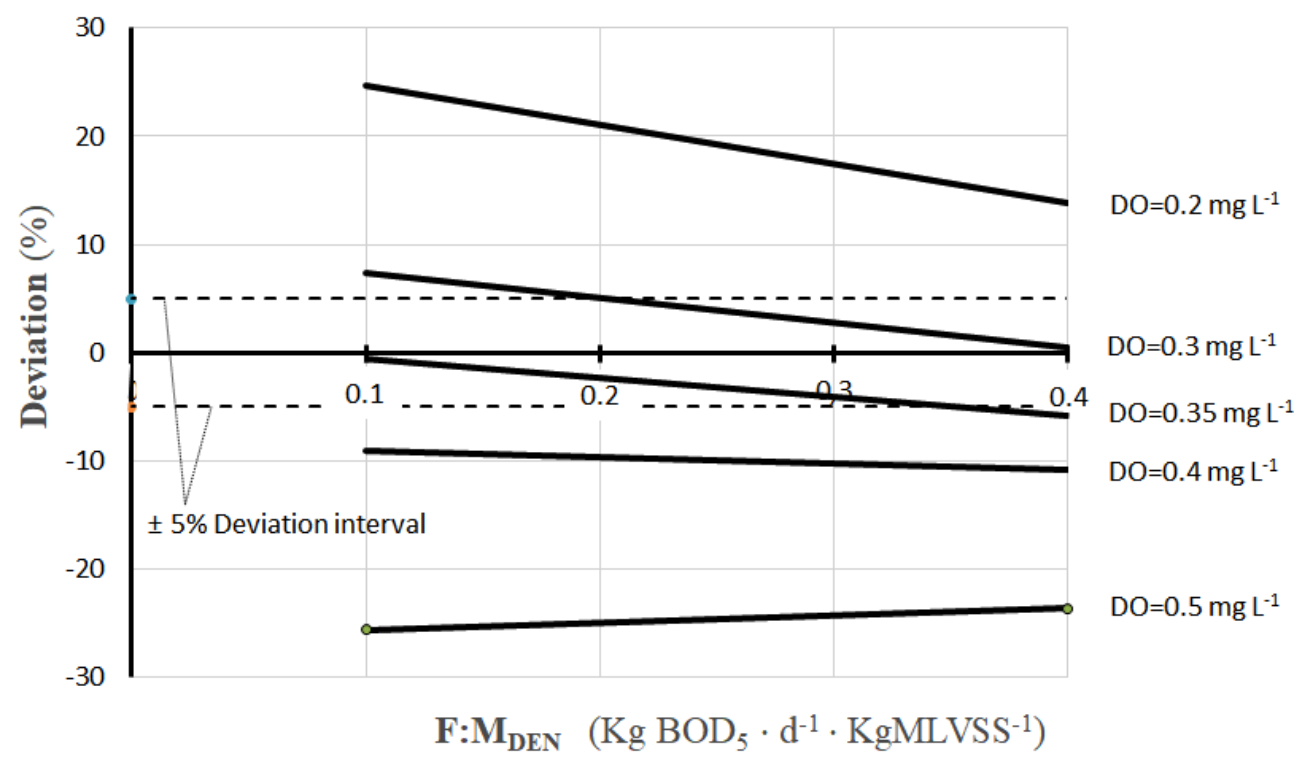

Figure 3. Deviation of $\mathrm{SDNR}_{20^{\circ} \mathrm{C}}$ of Models I from Model II (at different DO), as a function $F: M_{D E N}$.

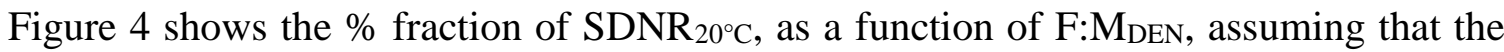
value relative to $\mathrm{F}: \mathrm{M}_{\mathrm{DEN}}=0.3 \mathrm{~kg} \mathrm{BOD}_{5} / \mathrm{kg} \mathrm{MLVSS}^{-1} \mathrm{~d}^{-1}$ is equal to $100 \%$.

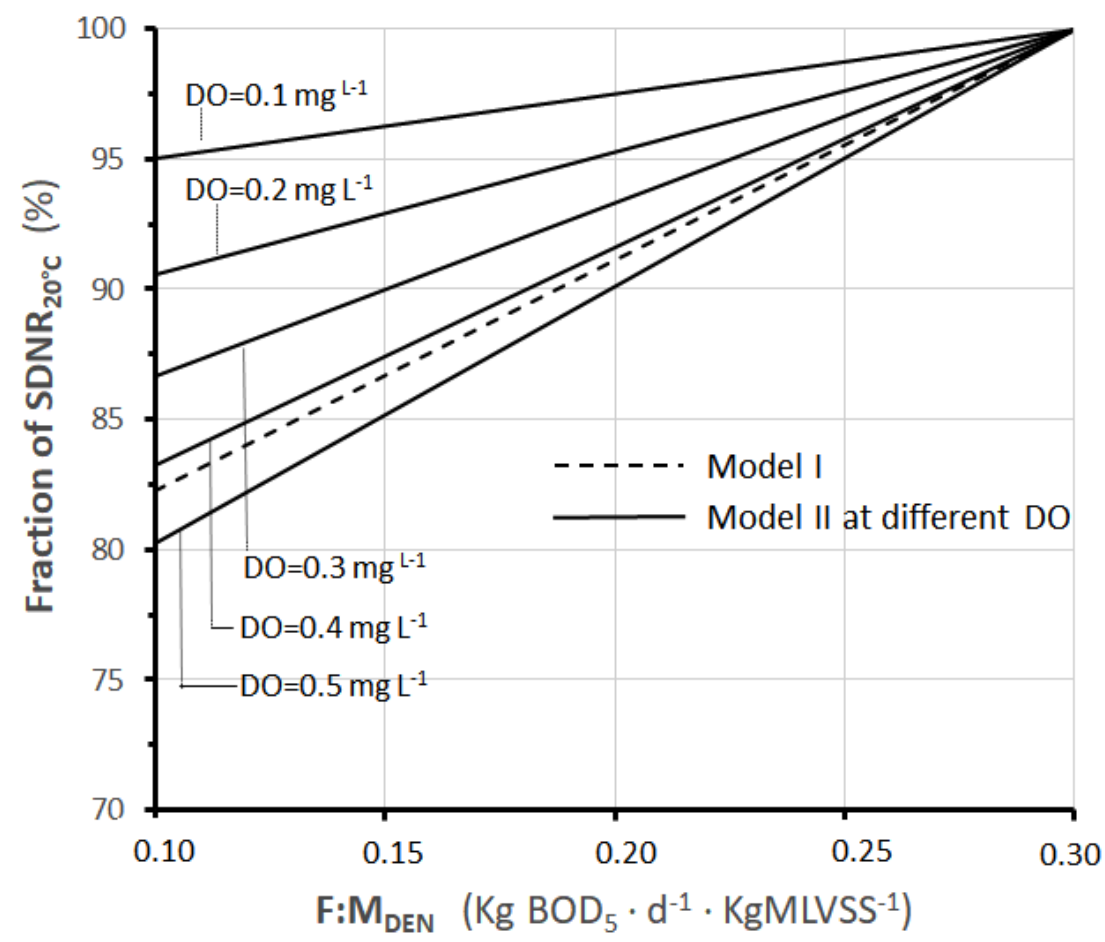

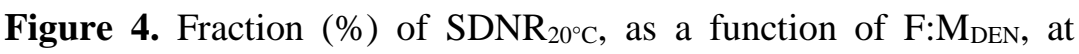

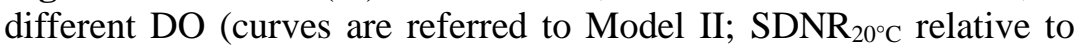
$\mathrm{F}: \mathrm{M}_{\mathrm{DEN}}=0.3$ is assumed equal to $100 \%$ ). 
It is noted the linear trend of all models. As regards to Model II, in correspondence of $\mathrm{DO}=0.3 \mathrm{mg} \mathrm{L}^{-1}$, a $6 \%$ reduction of $\mathrm{SDNR}_{20^{\circ} \mathrm{C}}$ is observed for any reduction of $\mathrm{F}: \mathrm{M}_{\mathrm{DEN}}=0.1$ $\mathrm{kgBOD}_{5} / \mathrm{d}^{-1} \cdot \mathrm{kg} \mathrm{MLVSS}^{-1}$. A reduction less and less marked occurs at lower DO values and vice versa at higher values.

Figure 5 shows the mathematical derivative $\frac{\partial \mathrm{SDNR}_{20^{\circ} \mathrm{C}}}{\partial \mathrm{F}: \mathrm{MDEN}}$ relative to models I and II. In this sensitivity analysis, this derivative has a significant importance because it expresses the direct response of $\mathrm{SDNR}_{20}{ }^{\circ} \mathrm{C}$ to the stresses of $\mathrm{F}: \mathrm{M}$ DEN.

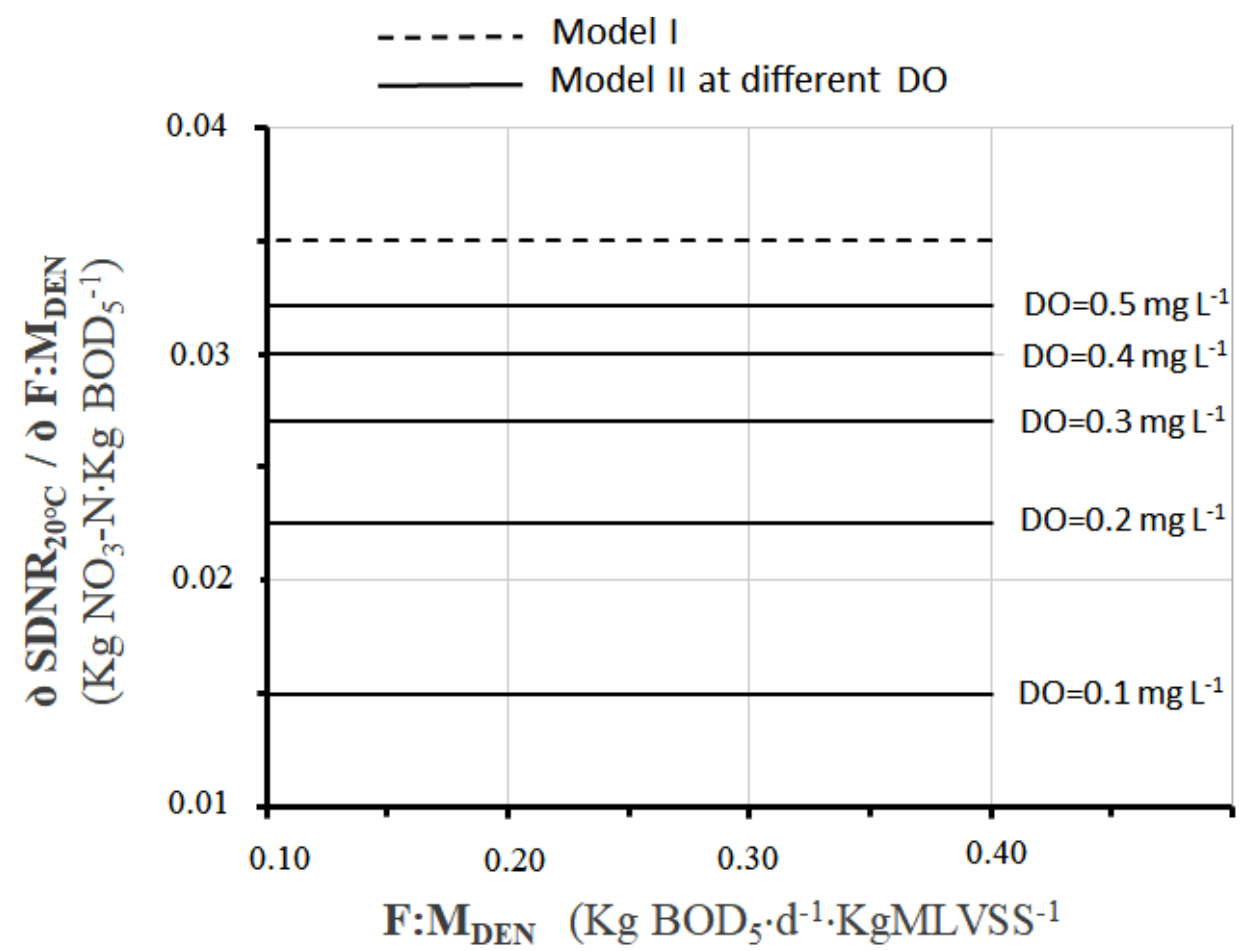

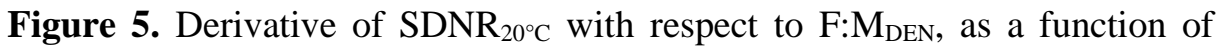
F:M $M_{\text {DEN }}$, according to Models I and Model II (at different DO).

As it can be seen, all derivatives are constant, due to the linear dependence of F: $M_{D E N}$ from

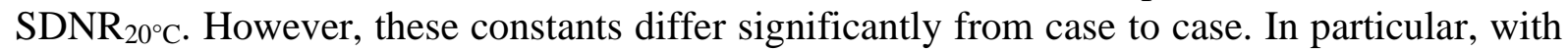
reference to Model II, they tend to get close to each other as DO concentrations increase.

Figure 6 shows very well the trend of the same derivative as a function of the DO. It is an increasing logarithmic curve with an asymptotic tendency to the value $\frac{\partial \mathrm{SDNR}_{20^{\circ} \mathrm{C}}}{\partial \mathrm{F}: \mathrm{MDEN}}=0.45 \mathrm{~kg}$ $\mathrm{NO}_{3}-\mathrm{N} \mathrm{kg} \mathrm{BOD}{ }_{5}^{-1}$. The strong initial gradient of the curve proves the lower sensitivity of $\mathrm{SDNR}_{20^{\circ} \mathrm{C}}$ to $\mathrm{F}: \mathrm{M}_{\mathrm{DEN}}$ at small DO concentrations, and vice versa. This graph is a further confirmation of how much also the DO variable can affect the denitrification kinetics and the consequent performance of the process.

Overall, the results of the present analysis highlight the need to keep the F:M $M_{D E N}$ as high

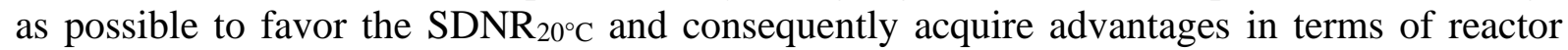
sizing and denitrification efficiency. However, F:M the sludge retention time-SRT is too small to determine the wash-out of the denitrifying heterotrophic bacteria, with consequent losses in efficiency. This limit is approximately in the range $\mathrm{F}: \mathrm{M}_{\mathrm{DEN}}=0.3-0.4 \mathrm{kgNO}_{3}-\mathrm{N} \mathrm{kgMLVSS}^{-1} \mathrm{~d}^{-1}$ where the lower value is suggested. There is

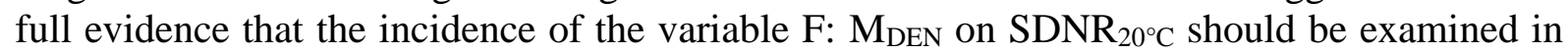
combination with the residual DO values in denitrification, which also significantly affects the efficiency of the process. 


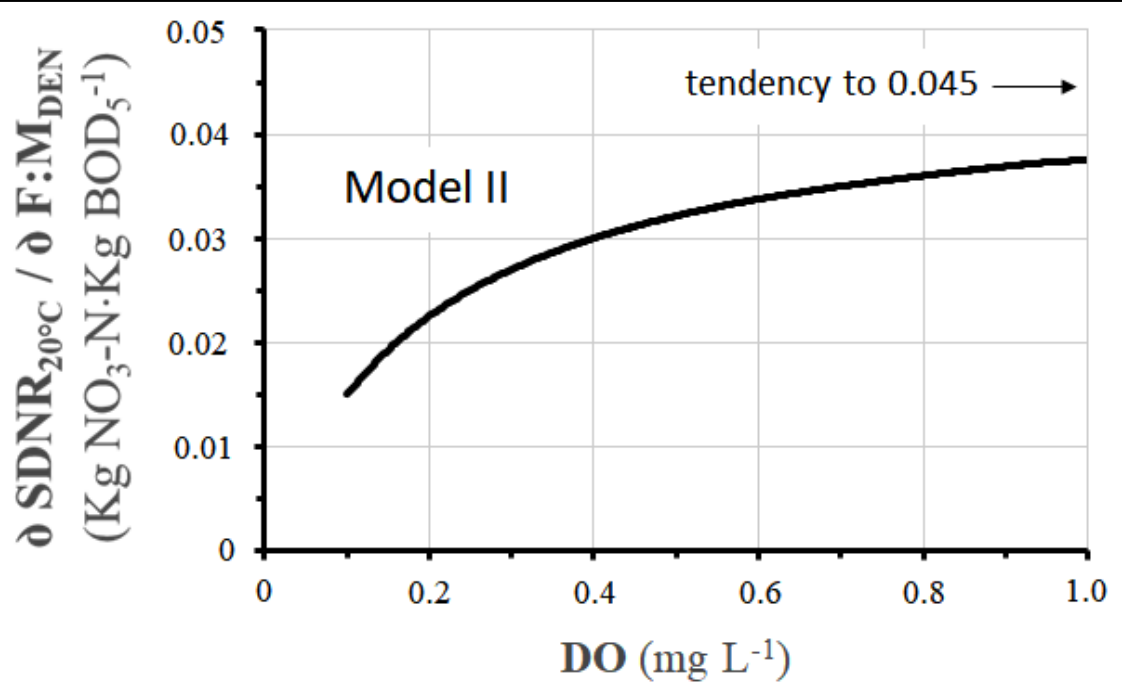

Figure 6. Derivative of $\mathrm{SDNR}_{20^{\circ} \mathrm{C}}$ with respect to $\mathrm{F}: \mathrm{M}_{\mathrm{DEN}}$ (according to Model II) as a function of DO.

\section{CONCLUSIONS}

The sizing of the biological pre-denitrification reactors as well as the denitrification efficiency are closely related to SDNR-specific denitrification rate. Two mathematical models

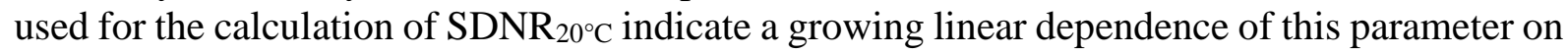
the sludge loading in denitrification (F:M $\left.M_{D E N}\right)$. Therefore high values of $F: M_{D E N}$ favor the $\mathrm{SDNR}_{20}{ }^{\circ} \mathrm{C}$ and consequently the sizing of the denitrification volume as well as the denitrification efficiency. However, F:M $M_{\text {DEN }}$ cannot exceed the limit beyond which the sludge retention time-SRT becomes too small to determine the wash-out of the denitrifying heterotrophic bacteria, with consequent losses in efficiency. This limit is approximately in the range $\mathrm{F}: \mathrm{M}_{\mathrm{DEN}}=0.3-0.4 \mathrm{kgNO}_{3}-\mathrm{N} \mathrm{kgMLVSS}^{-1} \mathrm{~d}^{-1}$ where the lower value is suggested.

Of the two models examined, one is purely empirical and the other more advanced, of a

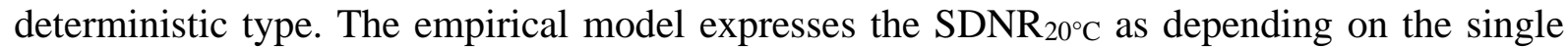
variable F:M $M_{\text {DEN }}$. Instead, the deterministic model expresses the $\mathrm{SDNR}_{20^{\circ} \mathrm{C}}$ as depending also on the dissolved oxygen in denitrification (DO).

The two models prove to be comparable only in a narrow range of DO (about DO $=0.25$ $0.35 \mathrm{mg} \mathrm{L}^{-1}$ ). However, values within this range are frequently found in well-designed and welloperated sewage treatment plants. Outside this range, the incidence of DO is relevant and cannot be neglected. All observations demonstrate a sensitivity of $\mathrm{SDNR}_{20^{\circ} \mathrm{C}}$ to $\mathrm{F}: \mathrm{M}_{\mathrm{DEN}}$ just as lower as smaller the DO concentrations are (DO $\left.<0.3 \mathrm{mg} \mathrm{L}^{-1}\right)$. At $\mathrm{DO}>0.3-0.4 \mathrm{mg} \mathrm{L}^{-1}$ this sensitivity tends progressively to grow towards an asymptotic value. There is extensive evidence that the impact on the process of the variable F:M $M_{D E N}$ should be examined in combination with the residual DO in denitrification.

\section{REFERENCES}

ABEYSIRIWARDANA-ARACHCHIGE, I. S. A.; MUNASINGHE-ARACHCHIGE, S. P. DELANKA-PEDIGE, H. M. K.; NIRMALAKHANDAN, N. Removal and recovery of nutrients from municipal sewage: Algal vs. conventional approaches. Water Research, v. 175, n. 115709, 2020. https://doi.org/10.1016/j.watres.2020.115709

BUTZEN, E. L.; CAPELLARI SANTOS, G.; SLONGO FORTUNA, S.; BARBOSA BRIÃO, V. Membrane bioreactor for mall wastewater treatment. Revista Ambiente \& Água, v. 15, n. 2, 2020. https://dx.doi.org/10.4136/ambi-agua.2489 
CAPODAGLIO, A. G.; HLAVÍNEK, P.; RABONI, M. Physico-chemical technologies for nitrogen removal from wastewaters: a review. Revista Ambiente \& Agua, p. 481-498, 2015. https://dx.doi.org/10.4136/ambi-agua.1618

CAPODAGliO, A. G.; HLAVÍNEK, P.; RABONI, M. Advances in wastewater nitrogen removal by biological processes: State of the art review. Revista Ambiente \& Agua, v. 11, p. 250-267, 2016. https://dx.doi.org/10.4136/ambi-agua.1772

COLlivignARELli, M. C.; ABBÀ, A.; BERTANZA, G.; DAMIANI, S.; RABONI, M. Resilience of a Combined Chemical-Physical and Biological Wastewater Treatment Facility. Journal of Environmental Engineering, v. 145, n. 7, 2019. https://dx.doi.org/10.1061/(ASCE)EE.1943-7870.0001543

COPELLI, S.; RABONI, M.; URBINI, G. Water Pollution: Biological Oxidation and Natural Control Techniques. In: REEDIJK, J. et al. (eds.). Reference module in chemistry, molecular sciences and chemical engineering. Waltham, MA: Elsevier, 2015. p 1-28. https://doi.org/10.1016/B978-0-12-409547-2.11419-2

EKAMA, G. A.; WENTZEL, M. C. Denitrification kinetics in biological N and P removal activated sludge systems treating municipal wastewaters. Water Science Technology, v. 39, n. 6, p. 69-77, 1999. https://doi.org/10.1016/S0273-1223(99)00124-9

EKAMA, G. A.; WILDERER, P. Biological Nutrient Removal. In: WILDERER, P. (ed.). Treatise on Water Science. Oxford: Elsevier, 2011. p. 409-526.

GERARDI, M. H. Nitrification and Denitrification in the Activated Sludge Process. New York: John Wiley \& Sons, 2002.

MAJOR BARBOSA, I.; MIERZWA, J. C.; HESPANHOL, I.; SUBTIL, E. L. Removal of nitrogen and organic matter in a submerged-membrane bioreactor operating in a condition of simultaneous nitrification and denitrification. Revista Ambiente \& Água, v. 11, n. 2, p. 304-315, 2016. https://dx.doi.org.br/10.4136/ambi-agua.1684

OH, J.; SILVERSTEIN, J. Oxygen inhibition of activated sludge denitrification. Water Research, v. 33, n. 8, p. 1925-1937, 1999. https://dx.doi.org/10.1016/S00431354(98)00365-0

PEREIRA RIBEIRO, R.; CYNAMON KLIGERMAN, D.; ZAMBONI DE MELLO, W.; DA PIEDADE SILVA, D.; DA FONSECA CORREIA, R.; LOPES DA MOTA OLIVEIRA, J. Effects of different operating conditions on total nitrogen removal routes and nitrous oxide emissions in a lab-scale activated sludge system. Revista Ambiente \& Água, v. 13, n. 2, 2018. https://dx.do.org/10.4136/ambi-agua.2174

PIRES DA SILVA, I.; BARBOSA DA COSTA, G.; THOMAZ QUELUZ, J.G.; LOUREIRO GARCIA, M. Effect of hydraulic retention time on chemical oxygen demand and total nitrogen removal in intermittently aerated constructed wetlands. Revista Ambiente \& Água, v. 15, n. 3, 2020. http://dx.doi.org/10.4136/ambi-agua.2504

PLÓSZ, B. G.; JOBBÁGY, A.; GRADY JR., C. P. L. Factors influencing deterioration of denitrification by oxygen entering an anoxic reactor through the surface. Water Research, v. 37, p. 853-863, 2003. https://doi.org/10.1016/S0043-1354(02)00445-1 
RABONI, M.; VIOTTI, P.; CAPODAGLIO, A. G. Experimental plant for the physicalchemical treatment of groundwater polluted by Municipal Solid Waste (MSW) leachate, with ammonia recovery. Revista Ambiente \& Agua, v. 8, n. 3, p. 22-32, 2013a. http://dx.doi.org/10.4136/ambi-agua.1250

RABONI, M.; TORRETTA, V.; URBINI, G. Influence of strong diurnal variations in sewage quality on the performance of biological denitrification in small community wastewater treatment plants (WWTPs). Sustainability, v. 5, n. 9, p. 3679-3689, 2013b. http://dx.doi.org/10.3390/su5093679

RABONI, M.; TORRETTA, V.; VIOTTI, P.; URBINI, G. Pilot experimentation with complete mixing anoxic reactors to improve sewage denitrification in treatment plants in small communities. Sustainability, v. 6, n. 1, p. 112-122, 2014a. http://dx.doi.org/10.3390/su6010112

RABONI, M.; TORRETTA, V.; VIOTTI, P.; URBINI, G. Calculating specific denitrification rates in pre-denitrification by assessing the influence of dissolved oxygen, sludge loading and mixed-liquor recycle. Environmental Technology, v. 35, n. 20, p. 2582-2588, 2014b. http://dx.doi.org/10.1080/09593330.2014.913690

RABONI, M.; GAVASCI, R.; VIOTTI, P. Influence of denitrification reactor retention time distribution (RTD) on dissolved oxygen control and nitrogen removal efficiency. Water Science Technology, v. 72, p. 45-51, 2015. https://dx.doi.org/10.2166/wst.2015.188

RABONI, M.; TORRETTA, V. Validation of a new model for the sizing of denitrification reactors, by testing full-scale plants. Environmental Technology, v. 38, p. 1376-1382, 2017. https://doi.org/10.1080/09593330.2016.1228700

RABONI, M.; VIOTTI, P. Predictive model of limestone scaling in ammonia stripping towers and its experimental validation on a treatment plant fed by MSW leachate-polluted groundwater. Waste Management, v. 59, p. 537-544, 2017. https://doi.org/10.1016/j.wasman.2016.10.025

SUBTIL, E. L.; HESPANHOL, I.; MIERZWA, J. C. Biorreatores com membranas submersas (BRMs): alternativa promissora para o tratamento de esgotos sanitários para reuso sp. Revista Ambiente \& Água, v. 8, n. 3, 2013. https://dx.doi.org/10.4136/ambi-agua.1684

TCHOBANOGLOUS, G.; BURTON, F. L.; STENSEL, H. D. Wastewater Engineering: Treatment and Reuse. McGraw-Hill, 2003.

TORRETTA, V.; RAGAZZI, M.; TRULLI, E.; DE FEO, G.; URBINI, G.; RABONI, M.; RADA, E. C. Assessment of biological kinetics in a conventional municipal WWTP by means of the oxygen uptake rate method. Sustainability, v. 6, p. 1833-1847, 2014. https://dx.doi.org/10.3390/su6041833

TORTI, E.; SIBILLA, S.; RABONI, M. An Eulerian-Lagrangian method for the simulation of the oxygen concentration dissolved by a two-phase turbulent jet system. Computers $\boldsymbol{\&}$ Structures, v. 129, p. 207-217, 2013. https://doi.org/10.1016/j.compstruc.2013.05.007

UCKER, F. E.; DE ARAÚJO ALMEIDA, R.; DA CUNHA KEMERICH, P. D. Removal of nitrogen and phosphorus from wastewater in a constructed wetland system using vetiver grass. Revista Ambiente \& Água, v. 7, n. 3, p. 87-98, 2012. http://dx.doi.org/10.4136/ambi-agua.925 
URBINI, G.; GAVASCI, R.; VIOTTI, P. Oxygen Control and Improved Denitrification Efficiency by Means of a Post-Anoxic Reactor. Sustainability, v. 7, n. 2, p. 1201-1212, 2015. https://dx.doi.org/10.3390/su7021201

USEPA. Nutrient Control Design Manual: State of Technology. EPA/600/R-09/0. 12. ed. Washington, 2009.

USEPA. Nutrient Control Design Manual. EPA/600/R-10/100. Washington, 2010.

VIOTTI, P.; COLLIVIGNARELLI, M. C.; MARTORELLI, E.; RABONI, M. Oxygen control and improved denitrification efficiency by dosing ferrous ions in the anoxic reactor. Desalination and Water Treatment, v. 57, n. 39, 2016. https://dx.doi.org/10.1080/19443994.2015.1089200

WUHRMANN, K. Nitrogen removal in sewage treatment processes. Taylor and Francis Online, 2017. p. 580-596. https://doi.org/10.1080/03680770.1962.11895576 